\title{
FROM INTERMITTENT CATHETERISATION TO CATHETER FREEDOM VIA URODYNAMICS: A TRIBUTE TO SIR LUDWIG GUTTMANN
}

\author{
By Alain B. Rossier, M.D. and Bushra A. Fam, M.D. \\ Urodynamic Laboratory of the Spinal Cord Injury Service, West Roxbury \\ Veterans Administration Medical Center, Boston, Ma. 02132, U.S.A.
}

\begin{abstract}
The diagnostic methods and treatments of neurogenic bladders are reviewed from the spinal shock period to the final stage of bladder function. Emphasis is placed upon intermittent catheterisation and urodynamic investigations with discussion on the respective value of some pharmacological agents and transurethral operations.
\end{abstract}

Key words: Neurogenic bladder; Urodynamics; Spinal shock.

\section{Introduction}

SINCE the management of a neurogenic bladder depends upon its correct diagnosis, it seems appropriate to discuss briefly our present methods for classifying the various types of neuromuscular micturitional dysfunction being aware of the fact that although it will not fit each and every case, it remains valid for an overwhelming majority of patients.

Apart from the sensory neurogenic bladder, e.g. tabes, and the motor neurogenic bladder, e.g. Parkinson, neurogenic bladders can be divided into upper and lower motor neuron lesions (UMNB and LMNB), or a combination of both types, the so-called mixed lesions (Table I). Apart from root injury in trauma to the thoracolumbar or lumbar region, the type and completeness of the cord damage will be determined by the level of cord involvement and by its extent within the grey and white matter, respectively. Additional structural intrinsic alterations of the detrusor secondary to chronic infection and overdistension may, however, act adversely on the bladder activity and cause it to deviate considerably from what should be expected from the initial cord level.

The investigation of the somatic component of the sacral reflexes consists of the examination of the anal tone and of the bulbocavernosus and anal reflexes whose synapses lie within the second to the fourth sacral segments. Weakened activity of the pelvic floor muscles, as can occur in borderline UMN lesions following thoracolumbar fractures, or mixed lesions with a lower motor neuron detrusor and an upper motor neuron external urethral sphincter may, however, be missed clinically and require EMG investigations of the external anal and urethral sphincters since it is known that not all the pelvic floor muscles always behave in the same way in neurologic diseases.

The investigation of the autonomic component of the sacral reflexes relies upon ice-water stimulation of the detrusor (Bors \& Comarr, I97I) or cystometry. Since false negative ice-water tests at bedside have been shown to occur in hypoactive UMNB and/or hyperactive external urethral sphincter (Rossier, Ott \& Roussan, I975), cystometric recordings with sterile iced dye solution may be the only way for disclosing true bladder activity and urethrovesical changes associated with bladder 


\section{TABLE I}

Classification of neurogenic bladders with a sensory-motor neuron deficit. Mixed lesions with an upper visceromotor component and a rather 'normal' somatomotor control can be found in incomplete upper motor neuron bladders. Mixed lesions with a lower visceromotor component and a rather 'normal' somatomotor control are especially to be found following extensive intrapelvic operations, e.g. radical hysterectomy

\section{IYPES AND CHARACTERISTICS OF NEUROGENIC BLADDERS}

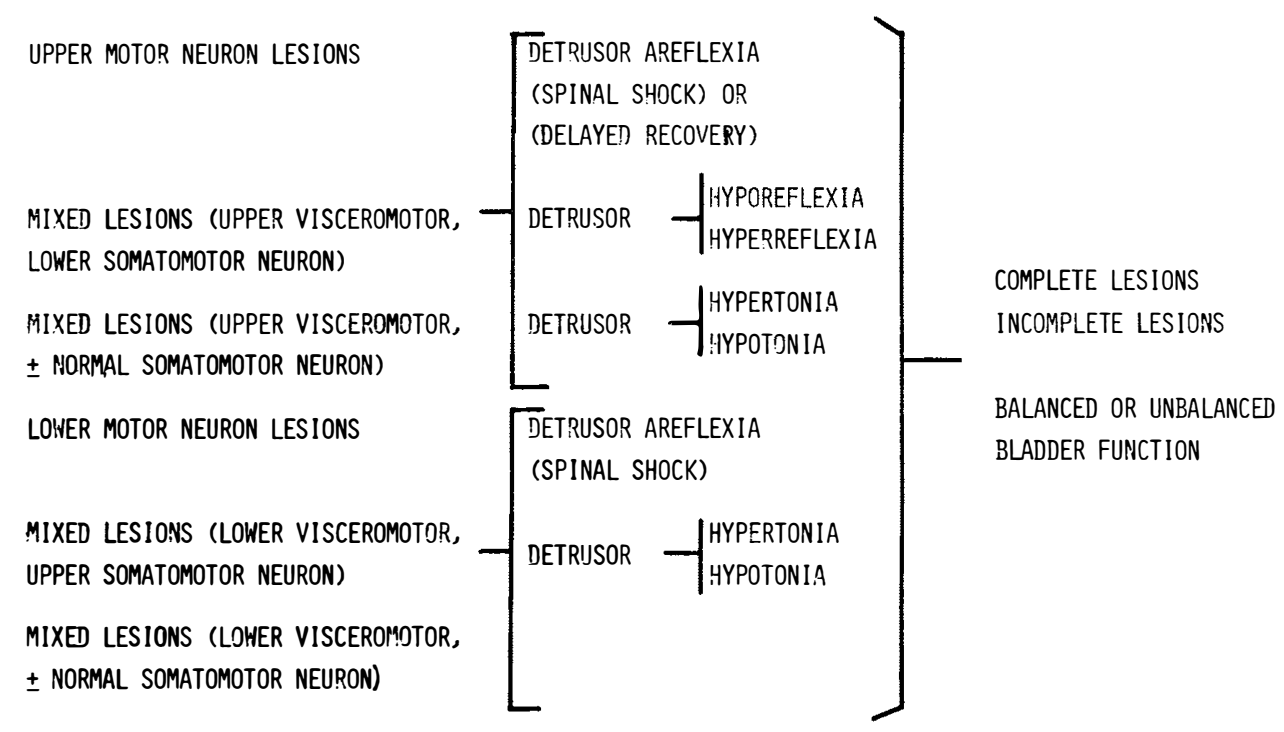

contraction. This fluoroscopically controlled chilled contrast test (CCT) should be carried out at the end of the cystometrographic recording in order not to alter the basic urethrovesical pattern. The CCT consists of filling up the bladder rapidly with $300 \mathrm{ml}$ of diatrizoate meglumine solution at $4{ }^{\circ} \mathrm{C}$. (Reno-M-Dip ${ }^{\mathrm{TM}}$ 30 per cent; Squibb \& Sons, New York) which runs freely by gravity at the average rate of $65 \mathrm{ml}$ per min. A I6 F Nelaton plastic catheter without balloon is utilised for filling the bladder, whereas a 5 or $6 \mathrm{~F}$ ureteral catheter placed in the bladder records the intracystic activity simultaneously with radiographic pictures of the bladder during filling, voiding, and post-void situations (Fig. I).

\section{Findings in the Acute Post-traumatic Period: Spinal Shock}

Most acute spinal cord injuries are followed by a period of so-called spinal shock with areflexia or markedly reduced deep tendon reflexes below the level of the lesion. Likewise, the bladder will usually prove to be inactive with no uninhibited waves, and hypotonic to varying degrees, but not atonic (Rossier, 1974). In Io of I6 patients in spinal shock during trials of voiding cysto-urethrogram (Credé manoeuvre, straining, tapping the bladder) the bladder neck was found to be closed or hardly open. The pressures recorded within the bladder neck were either identical to or higher than the pressures recorded in the bladder and most of the 


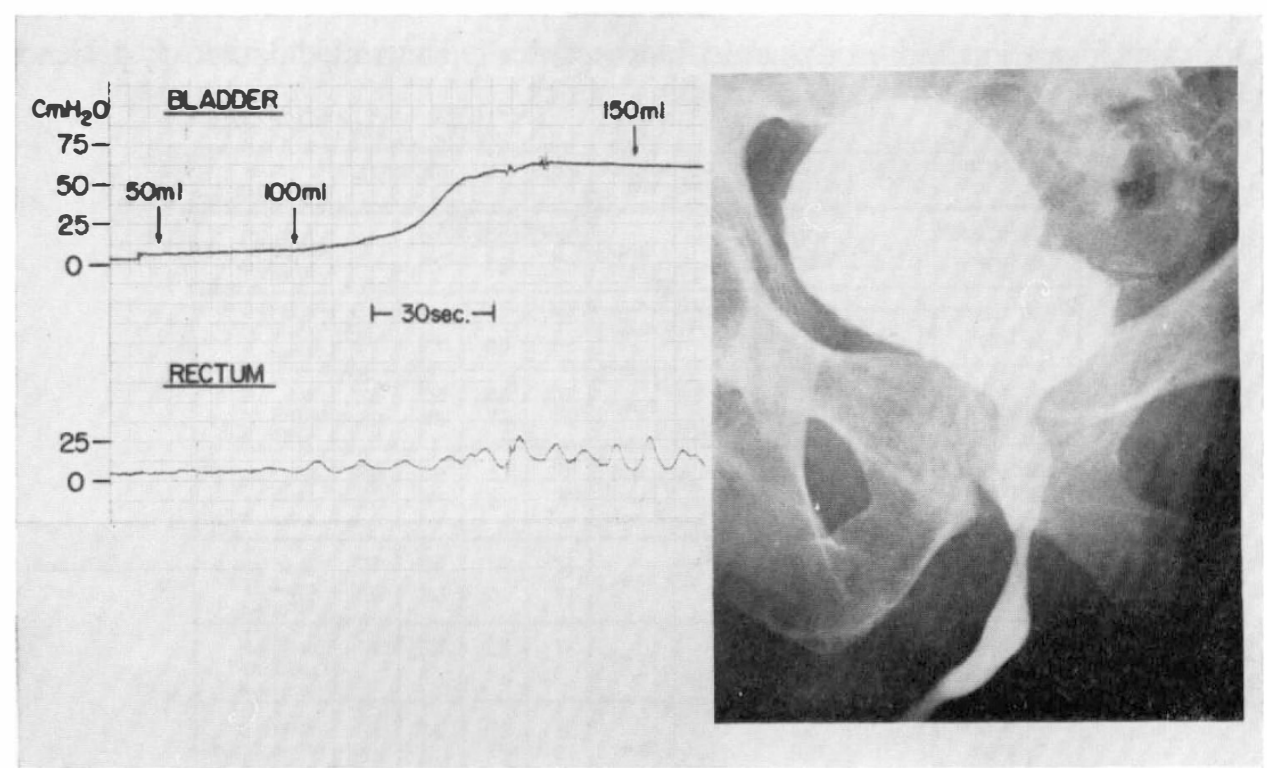

FIG. I

CCT in a 44-year-old white male with a traumatic flaccid paraplegia sensory incomplete L2-L3 and motor complete TI2-LI of 6 weeks' duration. With a bladder filling of $100 \mathrm{ml}$, an uninhibited wave of about $60 \mathrm{~cm} \mathrm{H}_{2} \mathrm{O}$ is shown in conjunction with a voiding cystourethrogram. This epiconal lesion had an UMNB and LMN somatomotor component (external urethral sphincter) as shown by the absence of all conus reflexes and fibrillation by EMG in both external urethral and anal sphincters.

time could not be related to the condition of the bladder neck seen on X-rays (Table II). Even in patients out of spinal shock it has been our experience that pressure measurements within the bladder neck are of very limited value in the overall urodynamic assessment of a patient with unbalanced bladder function and high residuals. It has also been shown that in spinal shock patients with UMNB and in whom membranous urethral sphincter resistance was recorded values did not always differ significantly from those found in patients not in spinal shock (Table II) (Rossier, 1974). It may, therefore, be concluded that the external urethral sphincter does not decrease its activity during spinal shock in the same manner as other striated muscles in which loss of tone is characteristic of this condition. Moreover, in a longitudinal study carried out in I3 patients during spinal shock and several weeks later on, increased urethral pressure profile values were found in the membranous urethra in nine of these patients after they went out of spinal shock and became spastic (Table III). These findings tend to support the fact that in spinal shock the striated component of the external urethral sphincter does not disclose its activity to its full extent.

Because of the aforementioned features characteristic of 'spinal shock bladder', i.e. closed bladder neck, marked activity within the membranous urethra, and hypotonic inactive bladder, it is contra-indicated to try to overcome the closing mechanisms of the bladder by the Credé manoeuvre because of the dangers of ureterovesical reflux and of bladder overdistension (Pearman \& England, 1973). 


\section{TABLE II}

Clinical information and urodynamic fluoroscopically controlled data in I 7 patients in spinal shock

\begin{tabular}{|c|c|c|c|c|c|c|c|c|c|}
\hline PATIENTS & $\left|\begin{array}{c}\text { DAYS } \\
\text { POST-INJ } \\
\text { CMG }\end{array}\right|$ & $\begin{array}{l}\text { BLADDER } \\
\text { VOLUME }\end{array}$ & $\mid \begin{array}{c}\text { BLADDER } \\
\text { PRES SURE }\end{array}$ & $\left|\begin{array}{l}\text { X-RAYS } \\
\text { BLADDER } \\
\text { NECK }\end{array}\right|$ & VUJ & $U_{1}$ & $U_{2}$ & $U_{3}$ & $\begin{array}{c}\text { CONUS } \\
\text { REFLEXES }\end{array}$ \\
\hline $\begin{array}{c}\text { I. W. H } 29 y r s . \\
C_{6} \text { Compl. }\end{array}$ & 5 & $\begin{array}{l}100 \\
400\end{array}$ & $\begin{array}{r}5 \\
10\end{array}$ & Closed & $\begin{array}{l}15 \\
15\end{array}$ & $\begin{array}{l}20 \\
20\end{array}$ & $\begin{array}{l}75 \\
70\end{array}$ & 45 & $\begin{array}{l}\text { BCG. }+ \\
\text { A.Tone: } 2 \\
\text { A Wink. }+\end{array}$ \\
\hline $\begin{array}{r}\text { 2. H.R. I9yrs } \\
T_{5} \text { Compl. }\end{array}$ & 1 & $\begin{array}{l}100 \\
250\end{array}$ & $\begin{array}{l}7 \\
8\end{array}$ & Closed & 25 & $\overline{25}$ & $\frac{-}{75}$ & $\frac{-}{70}$ & $\begin{array}{l}\text { BCG: }++ \\
\text { A.Tone: } 3+ \\
\text { A Wink: }+\end{array}$ \\
\hline $\begin{array}{l}\text { 3. MC. } 64 \mathrm{yrs} \\
\mathrm{T}_{4} \text { Compl. }\end{array}$ & 12 & $\begin{array}{l}100 \\
300\end{array}$ & $\begin{array}{l}2 \\
7\end{array}$ & Closed & $\begin{array}{l}20 \\
37\end{array}$ & $\begin{array}{l}35 \\
37\end{array}$ & $\begin{array}{l}35 \\
35\end{array}$ & $\begin{array}{l}62 \\
65\end{array}$ & $\begin{array}{l}\text { BCG: neg. } \\
\text { A.Tone: It } \\
\text { A.Wink + }\end{array}$ \\
\hline $\begin{array}{l}\text { 4. L.M } 29 \mathrm{yrs} \\
C_{6} \text { Compl. }\end{array}$ & 28 & $\begin{array}{c}50 \\
300\end{array}$ & $\begin{array}{l}2 \\
7\end{array}$ & $\begin{array}{c}\text { Closed } \\
\text { Slightly } \\
\text { Funneled }\end{array}$ & $\begin{array}{l}5 \\
7\end{array}$ & $\begin{array}{l}12 \\
12\end{array}$ & $\begin{array}{l}40 \\
37\end{array}$ & $\begin{array}{l}48 \\
52\end{array}$ & $\begin{array}{l}\text { BCG: neg. } \\
\text { A.Tone } 2+ \\
\text { A Wink: + }\end{array}$ \\
\hline $\begin{array}{l}\text { 5. K.R. } 21 \text { yrs. } \\
C_{8} \text { Compl. }\end{array}$ & 6 & $\begin{array}{l}150 \\
450\end{array}$ & $\begin{array}{r}2 \\
10\end{array}$ & Closed & $\begin{array}{l}18 \\
15\end{array}$ & $\begin{array}{l}18 \\
15\end{array}$ & $\begin{array}{l}55 \\
58\end{array}$ & $\begin{array}{l}80 \\
80\end{array}$ & $\begin{array}{l}\text { BCG: } \pm \pm \\
\text { A.Tone: } 3+ \\
\text { A.Wink: neg. }\end{array}$ \\
\hline $\begin{array}{l}\text { 6. F.T. } 29 \mathrm{yrs} . \\
\mathrm{C}_{7} \text { Compl. }\end{array}$ & 1 & 100 & 2 & Closed & 17 & 22 & 37 & 50 & $\begin{array}{l}\text { BCG: neg. } \\
\text { A.Tone: } 2+ \\
\text { A.Wink: neg. }\end{array}$ \\
\hline $\begin{array}{l}\text { 7. D.H. } 22 \mathrm{yrs} . \\
\mathrm{C}_{7} \text { Compl. }\end{array}$ & 2 & $\begin{array}{r}50 \\
350\end{array}$ & $\begin{array}{l}2 \\
2\end{array}$ & Closed & $\begin{array}{r}8 \\
10\end{array}$ & $\begin{array}{l}27 \\
37\end{array}$ & $\begin{array}{l}90 \\
110\end{array}$ & $\begin{array}{l}50 \\
50\end{array}$ & $\begin{array}{l}\text { BCG: }++ \\
\text { A.Tone } 3+ \\
\text { A.Wink: }+ \\
\end{array}$ \\
\hline $\begin{array}{r}\text { 8. H.A. } 17 \mathrm{yrs} . \\
\mathrm{C}_{5} \text { Compl. }\end{array}$ & 3 & $\begin{array}{c}50 \\
400\end{array}$ & $\begin{array}{l}2 \\
7\end{array}$ & Closed & $\begin{array}{l}10 \\
20\end{array}$ & $\begin{array}{l}10 \\
37\end{array}$ & $\begin{array}{l}50 \\
65\end{array}$ & $\begin{array}{l}62 \\
65\end{array}$ & $\begin{array}{l}\text { BCG: } \pm \\
\text { A.Tone: } 2+ \\
\text { A.Wink: }+\end{array}$ \\
\hline $\begin{array}{l}\text { 9. McG. J. I8yrs. } \\
C_{7} \text { Compl. }\end{array}$ & 4 & 300 & 10 & $\begin{array}{l}\text { Slightly } \\
\text { Funneled }\end{array}$ & 14 & 14 & 25 & 80 & $\begin{array}{l}\text { BCG: } \pm \\
\text { A.Tone: It } \\
\text { A Wink. + }\end{array}$ \\
\hline $\begin{array}{r}\text { IO. v. J. } 22 \text { yrs. } \\
\mathrm{C}_{4} \text { Compl. }\end{array}$ & 3 & $\begin{array}{r}30 \\
350\end{array}$ & $\begin{array}{l}5 \\
12\end{array}$ & Closed & $\begin{array}{l}5 \\
17\end{array}$ & $\begin{array}{l}12 \\
17\end{array}$ & $\begin{array}{l}75 \\
75\end{array}$ & $\frac{75}{-}$ & $\begin{array}{l}\text { BCG: ++ } \\
\text { A.Tone: } 3+ \\
\text { A Wink: neg. }\end{array}$ \\
\hline $\begin{array}{l}\text { II. McK L I8yrs. } \\
\mathrm{C}_{4} \text { Compl. }\end{array}$ & 2 & 50 & 2 & - & 25 & 25 & 95 & 75 & $\begin{array}{l}\text { BCG: } \pm \\
\text { A. Tone 3+ } \\
\text { A Wink + } \\
\end{array}$ \\
\hline $\begin{array}{l}\text { 12. A. D. } 23 \text { yrs. } \\
C_{6}-C_{7} \text { Compl. }\end{array}$ & 4 & $\begin{array}{r}50 \\
350\end{array}$ & $\left.\begin{array}{l}2 \\
4\end{array}\right\}$ & $\begin{array}{c}\text { Slightly } \\
\text { Funneled }\end{array}$ & $\begin{array}{l}2 \\
4\end{array}$ & $\begin{array}{r}6 \\
12\end{array}$ & $\begin{array}{c}75 \\
100\end{array}$ & $\begin{array}{l}80 \\
80\end{array}$ & $\begin{array}{l}\text { BCG: } \pm \\
\text { A.Tone } 2+ \\
\text { A.Wink }+\end{array}$ \\
\hline $\begin{array}{l}\text { 13. G.R. 33yrs. } \\
C_{6} \text { Compl. }\end{array}$ & 4 & $\begin{array}{c}50 \\
300\end{array}$ & $\left.\begin{array}{l}2 \\
5\end{array}\right\}$ & $\begin{array}{c}\text { Slightly } \\
\text { Funneled }\end{array}$ & $\begin{array}{c}10 \\
7\end{array}$ & $\begin{array}{l}10 \\
12\end{array}$ & $\begin{array}{l}50 \\
60\end{array}$ & $\begin{array}{l}62 \\
60\end{array}$ & $\begin{array}{l}\text { BCG } \pm \\
\text { A.Tone } 1 \pm \\
\text { A.Wink: } \pm \\
\end{array}$ \\
\hline $\begin{array}{l}\text { 14. } 0.0 .27 \mathrm{yrs} \\
\mathrm{C}_{4}-\mathrm{C}_{5} \text { Compl. }\end{array}$ & 4 & $\begin{array}{c}50 \\
400\end{array}$ & $\left.\begin{array}{l}2 \\
5\end{array}\right\}$ & $\begin{array}{l}\text { Slightly } \\
\text { Funneled }\end{array}$ & $\begin{array}{l}2 \\
5\end{array}$ & $\begin{array}{l}2 \\
9\end{array}$ & $\begin{array}{l}55 \\
70\end{array}$ & $\begin{array}{l}75 \\
85\end{array}$ & $\begin{array}{l}\text { BCG: } \pm \\
\text { A.Tone: } 2+ \\
\text { A. Wink: } \pm\end{array}$ \\
\hline $\begin{array}{l}\text { 15. H.R. 39yrs. } \\
T_{4}-T_{5} \text { Compl. }\end{array}$ & 4 & $\begin{array}{c}50 \\
400\end{array}$ & $\left.\begin{array}{l}2 \\
8\end{array}\right\}$ & $\begin{array}{l}\text { Slightly } \\
\text { Funneled }\end{array}$ & $\begin{array}{l}2 \\
8\end{array}$ & $\begin{array}{l}10 \\
15\end{array}$ & $\begin{array}{l}35 \\
60\end{array}$ & $\begin{array}{l}50 \\
62\end{array}$ & $\begin{array}{l}\text { BCG: } \pm \\
\text { A.Tone: } 2 \\
\text { A. Wink: } \pm \\
\end{array}$ \\
\hline $\begin{array}{r}\text { 16. Sm Th. 2lyrs. } \\
\mathrm{C}_{6}-\mathrm{C}_{7} \text { Compl. }\end{array}$ & 9 & $\begin{array}{r}50 \\
500\end{array}$ & $\begin{array}{r}3 \\
15\end{array}$ & $\begin{array}{c}\text { sl Funneled } \\
\text { Closed }\end{array}$ & $\begin{array}{r}3 \\
15\end{array}$ & $\begin{array}{l}14 \\
25\end{array}$ & $\begin{array}{l}48 \\
65\end{array}$ & $\begin{array}{l}75 \\
85\end{array}$ & $\begin{array}{l}\text { BCG: - } \\
\text { A.Tone } 2 \\
\text { A. Wink: + }\end{array}$ \\
\hline $\begin{array}{l}\text { 17. c.c. } 21 \text { yrs } \\
T_{4}-T_{5} \text { Compl. }\end{array}$ & 13 & $\begin{array}{c}50 \\
300\end{array}$ & $\begin{array}{l}3 \\
7\end{array}$ & Closed & $\begin{array}{l}3 \\
7\end{array}$ & $\begin{array}{l}15 \\
25\end{array}$ & $\begin{array}{l}50 \\
50\end{array}$ & $\begin{array}{l}90 \\
90\end{array}$ & $\begin{array}{l}\text { BCG: ++ } \\
\text { A Tone } 2 \\
\text { A. Wink ++ }\end{array}$ \\
\hline
\end{tabular}

In addition, in experimental spinal shock it has been shown that parasympathomimetic drugs such as bethanechol chloride may cause a marked rise of intra-urethral pressure and that their use is, therefore, to be proscribed during the spinal shock period (Tulloch \& Rossier, I975).

Whenever applicable, since first advocated more than 30 years ago by Sir Ludwig Guttmann (Guttmann, I947), intermittent catheterisation has been repeatedly shown to be the method of choice for draining the bladder. Patients are 
TABLE III

Urodynamic measurements in 13 patients during and after spinal shock

IN SPINAL SHOCK OUT OF SPINAL SHOCK

\begin{tabular}{|c|c|c|c|c|c|}
\hline \multicolumn{2}{|c|}{$\begin{array}{c}\text { Resistance In } \\
\mathrm{Cm}_{2} \mathrm{O}\end{array}$} & \multirow{2}{*}{$\begin{array}{l}\text { Days Post- } \\
\text { Inj. }\end{array}$} & \multicolumn{2}{|c|}{$\begin{array}{c}\text { Resistance In } \\
\mathrm{Cm} \mathrm{H}_{2} \mathrm{O}\end{array}$} & \multirow{2}{*}{$\begin{array}{l}\text { Wks. Post- } \\
\text { Inj. }\end{array}$} \\
\hline$U_{2}$ & $\overline{U_{3}}$ & & $U_{2}$ & $U_{3}$ & \\
\hline 37 & 50 & 1 & 200 & 125 & 15 \\
\hline 75 & 75 & 3 & 125 & 110 & 16 \\
\hline 95 & 75 & 2 & 125 & 120 & 16 \\
\hline 75 & 80 & 4 & 85 & 95 & 12 \\
\hline 50 & 62 & 4 & 62 & 100 & 13 \\
\hline 55 & 75 & 4 & 75 & 100 & 12 \\
\hline 35 & 50 & 4 & 95 & 85 & 12 \\
\hline 75 & 45 & 5 & 80 & 52 & 10 \\
\hline 55 & 80 & 6 & 50 & 87 & 36 \\
\hline 50 & 62 & 3 & 55 & 67 & 11 \\
\hline 48 & 75 & 9 & 45 & 70 & 13 \\
\hline 35 & 62 & 12 & 40 & 80 & 10 \\
\hline 40 & 48 & 28 & 35 & 65 & 20 \\
\hline
\end{tabular}

catheterised 3-4 times in 24 hours in order not to exceed a bladder capacity of $500 \mathrm{ml}$. The daily output must, therefore, be closely watched and maintained between 1500 and $2000 \mathrm{ml}$. In order to discover urinary infection at its very beginning and to treat it immediately, bacterial counts of the catheterised urine with culture and antibiogram are carried out, systematically, two to three times a week. It has been reported in the literature that 60 to 80 per cent of the patients treated initially with this technique can be expected to leave the centre with sterile urine (Guttmann \& Frankel, I966; Ott \& Rossier, I972; Fam et al., 1978).

Data mentioning the use of suprapubic drainage with small plastic catheters are yet too scarce for assessing the value of this method in spinal cord patients (Smith, Cook \& Burt, 1976; Fam et al., 1978). This technique, however, has value in the occasional cases where urethral trauma, adverse urethral reaction and/or repeated bleeding or stricture make intermittent catheterisation difficult.

During the first post-traumatic days, in patients with multiple injuries, who necessitate a close monitoring of diuresis and in patients with serious polyuria as can be found in tetraplegics, it may be best to resort to continuous straight drainage through a Gibbon plastic catheter (Gibbon, 1958) or an indwelling plastic balloon catheter. Under these circumstances it has been our experience that these catheters allow for maintenance of sterile urine for several days until the time when intermittent catheterisation can be resumed safely.

Whenever one lacks the necessary features for complying with adequate rules of intermittent catheterisation, it is best to resort to one of the aforementioned types 


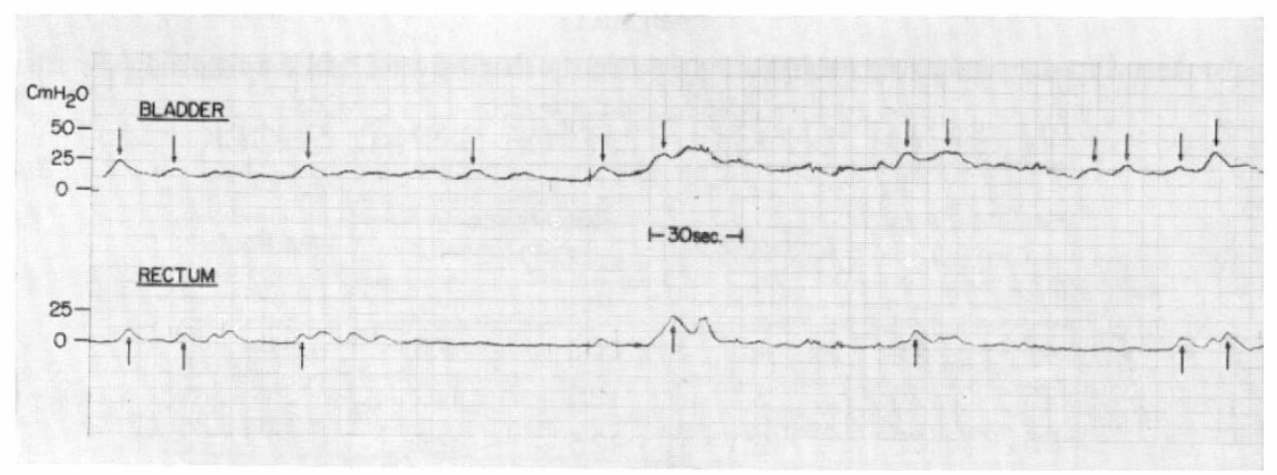

FIG. 2

Traumatic cauda equina lesion of 6 months' duration in a 44-year-old patient with a LMNB. Autonomous bladder waves can be seen which are for the most part unrelated to the intrinsic rectal activity. Bladder filling: $350 \mathrm{ml}$. The bladder which was initially hypotonic shows now a tendency towards hypertonicity.

of catheter, being aware of the known complications associated with the use of indwelling catheters.

\section{Diagnosis and Treatment past the Acute Post-traumatic Period}

\section{Lower Motor Neuron Type of Bladder}

In the initial stage the cystometrogram will show a hypotonic bladder which may display autonomous waves (Fig. 2). At a later date the bladder may become hypertonic, possibly because of the increase of alpha-receptors activity demonstrated in the detrusor of the parasympathetically denervated bladder (Sundin, Dahlström, Norlén \& Svedmyr, I977). The maximal urethral closing pressure does not usually exceed $40-50 \mathrm{~cm} \mathrm{H}_{2} \mathrm{O}$. This low value is similar to that one recorded in the bulbous urethra ( $\mathrm{U}_{4}$ ) of patients with $\mathrm{UMNB}$ as well as with $\mathrm{LMNB}$, i.e., beyond the point of highest urethral pressure usually located in $\mathrm{U}_{3}$ (Fig. 3) (Rossier \& Ott, I974; Rossier, Ott \& Roussan, I975). EMG of the external urethral sphincter will show one or several of the usual signs of denervation, i.e. fibrillation, positive sharp waves, or polyphasic potentials.

Evacuation of this type of bladder is generally easier since the reflex arc of the external sphincter is interrupted and since the innervation of the abdominal muscles is undamaged (T5-T6 to RI2-LI segments). The paraplegic will, therefore, be able to make use of his abdominal muscles to empty the bladder in straining with possible additional help of Credé manoeuvre. When the bladder function remains unbalanced with high residuals a transurethral bladder neck incision or resection is indicated at the time the patient is active in a wheelchair and able to express his bladder contents manually in a proper way. Such an operation should, therefore, not be considered before the 3 rd or 4 th month post-injury. As an alternative to surgery it is worthwhile trying a medical treatment with alpha-adrenergic blocking agents such as phenoxybenzamine since adrenergic ganglion cells and fibres have been described in the bladder neck and proximal urethra of different mammalian species, as well as in humans (Nergårdh \& Boréus, I972; Caine, Raz \& Zeigler, 


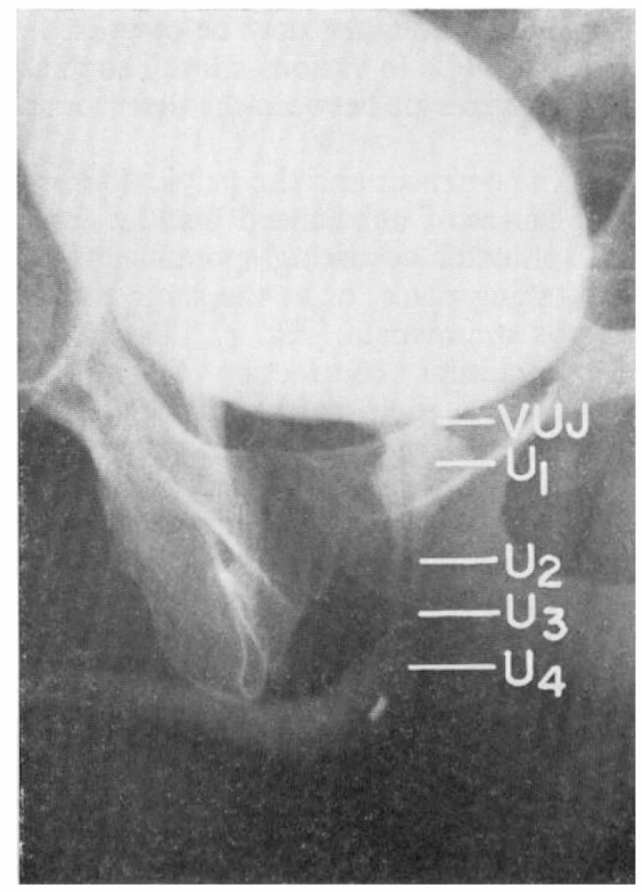

FIG. 3

Voiding cysto-urethrogram showing the various points of reference measured in our urodynamic studies. VUJ $=$ vesico-urethral junction. $\mathrm{U}_{\mathrm{I}}=$ prostatic urethra. $\mathrm{U}_{2}=$ beginning of the membranous urethra. $\mathrm{U}_{3}=$ distal part of the membranous urethra. $\mathrm{U}_{4}=$ bulbous urethra.

1975). Alpha adrenergic blocking agents have been shown to be useful in the treatment of lower motor neuron bladder (Stockamp \& Schreiter, 1975).

In patients with lower motor neuron bladder and flaccid pelvic floor muscles the membranous urethra does not usually present an obstacle to voiding. However, in some instances fibrotic stenosis of the sphincter in cases of long-standing spinal cord injury (Cukier et al., 197I) or overactivity of the sympathetic system with ensuing contraction of the smooth urethral muscles may explain why some of these patients disclose a bladder neck widely open on straining but cannot, however, empty their bladder contents properly (Abel, Gibbon, Jameson \& Krishnan, I974). Mechanical kinking at the level of the prostato-membranous junction during straining may be another cause of obstruction in some other cases (Dollfus, Juraschek, Jacob-Chia \& Peter, 1972).

\section{Upper Motor Neuron Type of Bladder}

As soon as signs of bladder activity appear (ice-water test positive, uninhibited waves on the cystometrogram, spontaneous or provoked voiding) the number of catheterisations is progressively reduced according to the amount of residual urine until a balanced bladder function is eventually brought about (residual urine about $50 \mathrm{ml}$ ). Bladder retraining essentially makes use of the automatism of the detrusor after ascertaining what factors will best initiate micturition. In case of prolonged unbalanced bladder function with elevated residual urine, further urodynamic 
investigations are carried out for determining which medical and/or surgical treatment is indicated. Cystosphincterometry may be of great help in demonstrating the reactions of the detrusor muscle to various stimuli such as tapping the bladder and in pointing at possible dyssynergia between the detrusor and the external urethral sphincter.

Dyssynergia between the detrusor and the pelvic floor muscles is known to be one of the most common causes of unbalanced bladder function, e.g. clonic contractions of the external sphincter occurring spontaneously, or at the same time detrusor contractions are taking place, or at the same time a bladder stimulus is applied to promote detrusor automatism (Fig. 4). By the same token micturition may be abruptly halted by voluntary contraction of the abdominal muscles or the Credé manoeuvre which may both elicit spasms of the pelvic floor muscles including the external urethral sphincter. Dyssynergia may represent a major obstacle to bladder rehabilitation especially in cases of hypoactive detrusor and hyperactive external urethral sphincter. Combined cystosphincterometry which makes use of a single catheter for filling the bladder and for conducting simultaneous bladder and urethral sphincter pressure recordings with constant urethral infusion has been shown to be a valuable method in the evaluation and treatment of neurogenic vesico-urethral dysfunctions (Fig. 5) (Rossier, Fam, DiBenedetto \& Sarkarati, I978).

Additional EMG sphincter recordings and possibly flow rates measurements may bring out valuable information to supplement pressure monitoring data. Low residual urines, per se, do not exclude detrusor-sphincteric imbalance since high intracystic pressures may need to be generated to overcome exaggerated outlet resistance and to bring down residual urine to acceptable levels. This imbalance may lead to secondary upper tract deterioration and may only be assessed by repeated urodynamic investigations.

Bethanechol chloride should be used with caution since it has been shown that it may precipitate arrhythmic activity within the membranous urethra as well as give way to concomitant uninhibited detrusor waves (Yalla, Rossier \& Fam, 1976).

Following the administration of alpha-adrenergic blocking agents favourable clinical effects have occasionally been reported in upper motor neuron lesions, especially in incomplete ones (Krane \& Olsson, I973; Awad, Downie \& Kiruluta, I978). In spinal cord injured patients with complete upper motor neuron bladder in whom we tried this treatment overall results have been extremely disappointing, probably because the overactive striated urethral component which has been shown to extend anatomically up to the bladder neck (Bors, Comarr \& Reingold, 1954) overrides the effect of the medication. This hypothesis gets some supporting evidence from one of the few favourable response to this drug which occurred in a 22-year-old patient with a traumatic complete $\mathrm{C}^{-}-\mathrm{C}_{7}$ tetraplegia whose bladder neck did not open well and whose residuals remained high (I00-I $50 \mathrm{ml}$ ) following external sphincterotomy carried out 5 months post-injury. Phenoxybenzamine $30 \mathrm{mg}$ a day was started 3 months post-sphincterotomy. Following 3 days of this treatment residuals started to decrease, averaging $50 \mathrm{ml}$ until a balanced bladder function was eventually achieved and maintained with this drug for the past ro months (Fig. 6). In another I7-year-old patient with a traumatic complete T8 paraplegia of 5 months' duration even doses up to $60 \mathrm{mg}$ a day did not alter the residuals nor the appearance of the voiding cysto-urethrograms, although the patient had uninhibited waves reaching $70 \mathrm{~cm} \mathrm{H} \mathrm{H}_{2} \mathrm{O}$ but also high pressures within $\mathrm{U}_{2}-\mathrm{U}_{3}$ averaging $85 \mathrm{~cm} \mathrm{H}_{2} \mathrm{O}$. To sum up, alpha-adrenergic blocking medications seem to be of practically no value in the rehabilitation of complete upper motor 


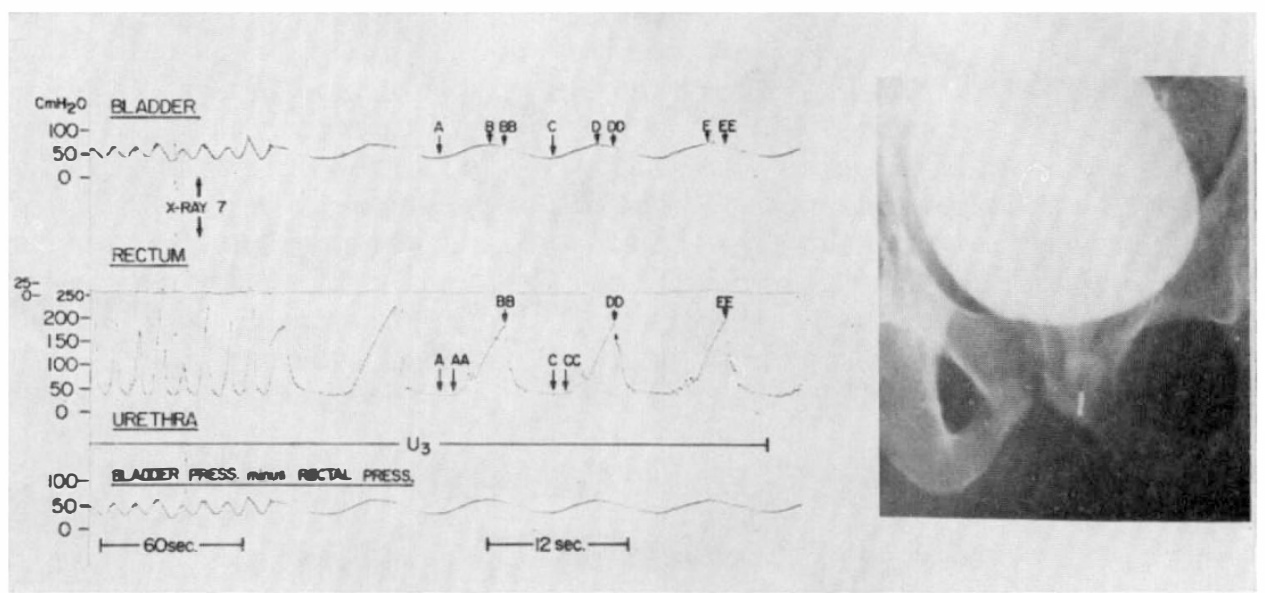

FIG. 4

Twenty-one-year-old male with a complete traumatic spastic paraplegia $\mathrm{T}_{3}$ of 3 months' duration. Typical caseof detrusor-sphincter dyssynergia. The radio-opaque catheter marker can be seen located in $U_{3}$. It is of interest that the beginning $(A, C)$ and the peak $(B, D)$ of bladder contractions precede by I to $\mathrm{I} \cdot 5 \mathrm{sec}$ those of the external urethral sphincter, AA, CC, and $\mathrm{BB}, \mathrm{DD}$, respectively.

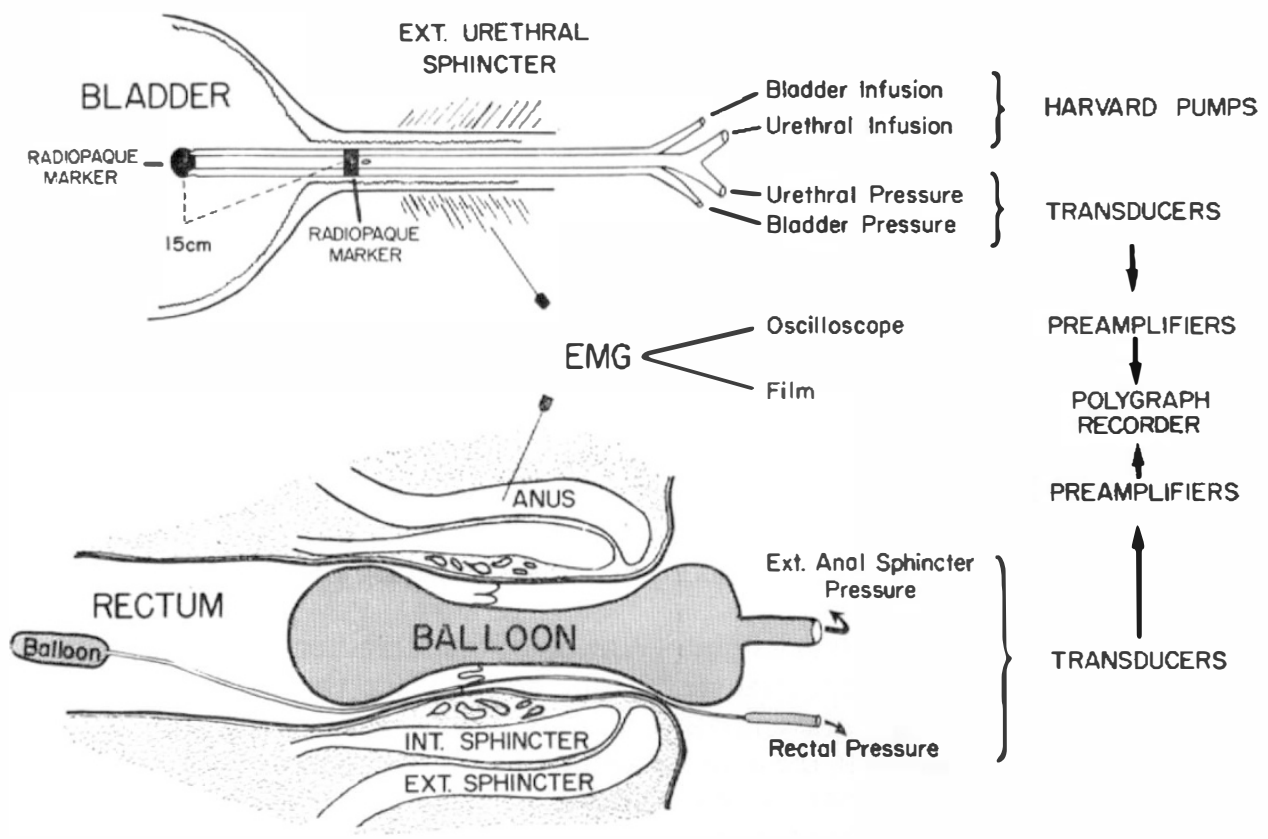

FIG. 5

Diagrammatic representation of the set-up utilised for urodynamic investigations. 

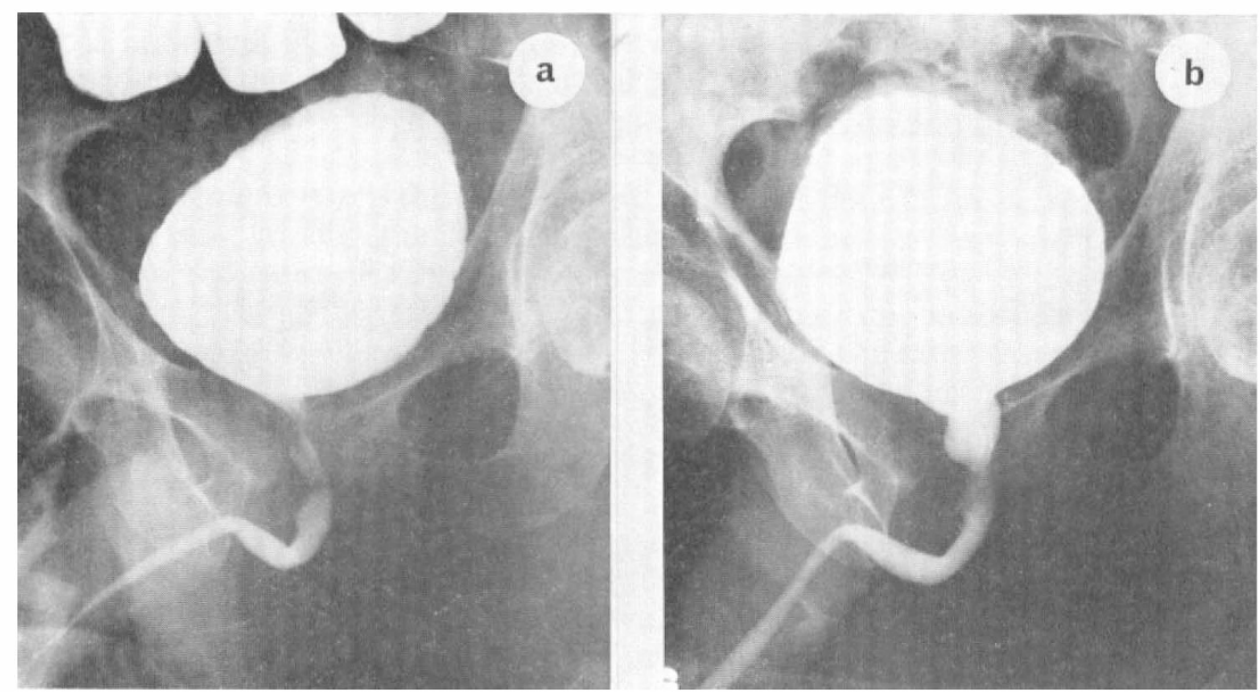

FIG. 6

Before phenoxybenzamine treatment. (a) Voiding cysto-urethrogram 3 months postexternal sphincterotomy. Bladder neck partially open. Bladder contents: $300 \mathrm{ml}$. Urine sterile. Residuals between 100 and $150 \mathrm{ml}$. (b) Voiding cysto-urethrogram I I days after the beginning of phenoxybenzamine. Bladder neck well patent. Bladder contents: $300 \mathrm{ml}$. Urine sterile. Residuals between 50 and $80 \mathrm{ml}$.

neuron bladders unless the obstacle presented by the spastic membranous urethra is relieved surgically and provided the detrusor displays sufficient activity as to assist in the opening of the vesical outlet.

Bladder and urethral mucosal anaesthesias may be used for decreasing pelvic floor muscles' spasticity since it has been demonstrated that topical anaesthesia of mucosal receptors will influence the recruitment of sensory afferents to the sacral segments and inhibit overactive pelvic floor muscles (Bors \& Comarr, I97I).

Although renewed interest has been expressed recently in pudendal neurectomy, external sphincterotomy does not interfere as much with sexual function, especially when carried out at 12 o'clock. It leaves the innervation to the external anal sphincter undamaged and seems to be the procedure of choice in demonstrable vesico-urethral dyssynergia (Rossier \& Ott, I974: Madersbacher \& Scott, I975).

In patients, especially females, with incomplete upper motor neuron lesions and urinary incontinence secondary to detrusor hyperactivity, when anticholinergic drugs such as methantheline and topical mucosal anaesthesias are inefficient to bring bladder incoordination back under control, differential sacral blocks followed by alcoholisation or neurotomies have yielded encouraging results (Susset, Zinner \& Archimbaud, I974).

Before any type of destructive intervention of the sacral roots is considered it is advisable to carry out differential sacral root blocks since the visceromotor components to the detrusor-parasympathetic motor fibres run out together with the somatomotor components to the external sphincter in the anterior sacral nerve roots. Depending upon whether therapy is aiming at sphincter spasticity relief or at abating detrusor hyperactivity makes it mandatory to determine the respective activity of each root with regard to its predominance either upon the detrusor or else upon the external urethral sphincter. 


\section{Mixed Type of Neurogenic Bladder}

This is a combination of both previous types of bladder, with either a detrusor of the upper motor neuron type and an external sphincter of the lower motor neuron type, or vice versa (Table I) (Fig. I). Such a condition is particularly to be found in traumatic lesions at the level of the conus medullaris (TII, TI2, LI and L2 vertebrae) where the sacral segments lie, i.e. where the somatic and autonomic nervous cells and roots which are implicated in vesico-urethral activity are in close proximity. This type of bladder is also frequently found in children with myelomeningocele. Diagnosis of this type of bladder may be difficult. Besides the usual urologic and neurologic diagnostic methods, electromyographic studies of the external anal and urethral sphincters may be indicated in differentiating an upper from a lower somatic motor neuron lesion.

Therapy of mixed neurogenic bladder with a detrusor of the upper motor neuron type and a sphincter of the lower motor neuron type will be usually easy to achieve since dyssynergia will be inexistent. Whatever the situation the treatment of a mixed lesion will consist of utilising, as needed, the same guidelines described in upper and lower motor neuron bladders. Following the aforementioned methods of treatment, it has been our experience that over 95 per cent of patients will achieve successful bladder rehabilitation and will become catheter-free eventually.

\section{SUMMARY}

The diagnostic methods of neurogenic bladder are reviewed and the initial treatment during spinal shock is discussed placing the emphasis upon the value of intermittent catheterisation. In upper motor neuron lesions it is shown that the external urethral sphincter displays a high resistance during spinal shock and that in the chronic post-traumatic phase dyssynergia between the detrusor and the pelvic floor muscles is one of the most common causes of unbalanced bladder function. The use of various drugs acting upon the detrusor and the bladder outlet and the respective role of external sphincterotomy and of neurotomies is discussed with regard to the neurological type of bladder.

\section{RÉSUMÉ}

Les auteurs passent en revue les méthodes de diagnostic des vessies neurologiques et discutent du traitement vésical initial pendant la période de choc médullaire, soulignant la valeur des sondages intermittents. Il est démontré que, dans les lésions du neurone moteur supérieur, même pendant le choc médullaire, le sphincter urétral externe révèle une résistance élevée, alors que la dyssynergie détrusor-muscles du plancher pelvien, cause la plus fréquente d'une fonction vésicale inadéquate et déséquilibrée, caractérise la phase posttraumatique établie. Les auteurs discutent la valeur respective de diverses médications sur le détrusor et le col vésical, mentionnant le rôle particulier de la sphinctérotomie externe et celui des neurotomies sélectives fonction du type de vessie neurologique.

\section{ZUSAMMENFASSUNG}

Die diagnostischen Methoden der neurogenen Blasen und die anfängliche Behandlung während des spinalen Shocks sind erötert. Das Wert des intermittierenden Katheterismus ist unterstrichen. In Läsionen des oberen motorischen Neurons zeigt der äussere Urethralsphinkter eine Widerstanserhöhung ebenso während des spinalen Shocks. Während des chronischen posttraumatischen Stadiums stellt die Detrusor-Sphinkter-Dyssynergie die übliche Ursache von unausgeglichener Blasenfunktion vor. Verschiedene Medikamente mit Angriffspunkte auf den Detrusor und den Blasenhals sowie die Rolle der äusseren Sphinkterotomie und der selektiven Nervenblockade sind diskutiert. 


\section{REFERENCES}

Abel, B. J., Gibbon, N. O. K., Jameson, R. M. \& Krishnan, K. R. (1974). The neuropathic urethra. Lancet, 2, I229.

Awad, S. A., Downie, J. N. \& Kiruluta, G. H. (I978). Alpha-adrenergic agents in urinary disorders of the proximal urethra. Part II. Urethral obstruction due to 'Sympathetic dyssynergia'. Brit. F. Urol., 50, 336.

Bors, E. \& Comarr, A. E. (I97I). Neurological Urology. Physiology of Micturition: its Neurological Disorders and Sequelae. University Park Press, Baltimore.

Bors, E., Comarr, A. E. \& Reingold, I. M. (1954). Striated muscle fibers of the vesical neck. F. Urol., 72, I9I.

Caine, M., Raz, S. \& Zeigler, M. (1975). Adrenergic and cholinergic receptors in the human prostate, prostatic capsule and bladder neck. Brit. F.Urol., 47, I93.

Cukier, J., Leger, P., Benhamou, G., Lacombe, MME MAury, M. \& Couvelaire, R. (I97I). La myotomie chirurgicale du sphincter strié de l'urethre. Une nouvelle voie d'abord sous pubienne. Contribution à l'étude de la pathologie du sphincter strié du paraplégique. F. Urol. Néphrol., 77, 27.

Dollfus, P., Juraschek, F., Jacob-Chia, D. \& Peter, R. (1972). Prostato-cystopexy for a paraplegic case with an inactive bladder and perineum. Paraplegia, ro, 64.

Fam, B. A., Rossier, A. B., Blunt, K., Gabilondo, F. B., Sarkarati, M., Sethi, J. \& YALLA, S. V. (1978). Experience in the urologic management of 120 early spinal cord injury patients. F. Urol., 119, 485.

GibBon, N. (1958). A new type of catheter for urethral drainage of the bladder. Brit. $\mathcal{F}$. Urol., 30, I.

GuttmanN, L. (1947). Discussion on the treatment and prognosis of traumatic paraplegia. Proc. Roy. Soc. Med., 40, 219.

GutTMANN, L. \& FRANKEL, H. (1966). The value of intermittent catheterisation in the early management of traumatic paraplegia and tetraplegia. Paraplegia, 4, 63.

KRANe, R. J. \& Olsson, C. A. (I973). Phenoxybenzamine in neurogenic bladder dysfunction. II. Clinical considerations. F. Urol., I10, 653.

Madersbacher, H. \& SCOTT, F. B. (I975). Twelve o'clock sphincterotomy: technique, indications, results. Urol. Int., 30, 75 .

NERGÅRDH, A. \& BORÉUS, L. O. (I972). Autonomic receptor function in the lower urinary tract of man and cat. Scand. F. Urol. Nephrol., 6, 32.

OTt, R. \& Rossier, A. B. (1972). The importance of intermittent catheterization in bladder reeducation of acute traumatic spinal cord lesions. Proc. EighteenthVeterans Administration Spinal Cord Injury Conf., p. I39. U.S. Government Printing Office, Washington, D.C.

Pearman, J. W. \& England, E. J. (1973). The Urological Management of the Patient following Spinal Cord Injury. C. C. Thomas, Springfield.

Rossier, A. B. (1974). Neurogenic bladder in spinal cord injury. Management of patients in Geneva, Switzerland, and West Roxbury, Massachusetts. Urol. Clin. (N. Amer.), I, 125 .

Rossier, A. B., Fam, B. A., DiBenedetto, M. \& Sarkarati, M. (1978). Urodynamic and electromyographic assessment of urethro-vesical activity in spinal shock patients. VIIIth International Continence Society Meeting, 3 I August-2 September 1978, Medical School Manchester, p. I23, Pergamon Press, Oxford.

Rossier, A. B. \& OTT, R. (I974). Urinary manometry in spinal cord injury: a follow-up study. Value of cysto-sphincterometrography as an indication for sphincterotomy. Brit. F. Urol., 46, 439.

Rossier, A. B., OTT, R. \& Roussan, M. S. (1975). Urinary manometry in patients with spinal cord injury: neurological considerations in the rehabilitation of acute and chronic neurogenic bladder. Arch. Phys. Med. Rehab., 56, 187.

SMith, P. H., Cook, J. B. \& BURT, A. A. (1976). Percutaneous cystostomy in paraplegia: a follow-up of 4I patients. Paraplegia, I4, I35.

StockAMP, K. \& SCHREITER, F. (I975). Alpha-adrenolytic treatment of the congenital neuropathic bladder. Urol. Int., 32, 33.

Sundin, T., DAhlström, A., NorlÉN, L. \& Svedmyr, N. (I977). The sympathetic innervation and adrenoreceptor function of the human lower urinary tract in the normal state and after parasympathetic denervation. Invest. Urol., 14, 322. 
Susset, J. G., Zinner, N. \& ARChimbaud, J. P. (1974). Differential sacral blocks and selective neurotomies in the treatment of incomplete upper motor neuron lesion. Urol. Int., 29, 236.

Tulloch, A. G. S. \& Rossier, A. B. (1975). The autonomic nervous system and the bladder during spinal shock: an experimental study. Paraplegia, 13, 42.

Yalla, S. V., Rossier, A. B. \& FAM, B. (I 976). Dyssynergic vesicourethral responses during bladder rehabilitation in spinal cord injury patients: effects of suprapubic percussion, Credé method and bethanechol chloride. F. Urol., 115, 575. 